\title{
INVOLVEMENT OF THE BILIARY TRACT IN
}

\section{ACUTE HEPATITIS}

\author{
G. Sotgiu, M.D. \\ Instituto di Clinica Medica Generale, University of Bologna, Italy.
}

THE SUBJECT I intend to discuss this evening deals with the involvement of the biliary tract and in particular of the large biliary ducts in acute hepatitis. It is very difficult to study these ducts in hepatitis, because these effects are largely overshadowed by those of the parenchymal lesion. Radiological investigation is of no help unless we try to do direct cholangiography through an intrahepatic or intracholecysticRoyer's-injection. Biopsy of the biliary ducts is not possible. There is nothing left to do but duodenal drainage, a technique and interpretation, as we know, offering many disadvantages and difficulties. So we often fail to pay the biliary tract sufficient attention, or even tend to neglect it altogether.

We have been carrying out research on this problem for a long time, and have been able to verify that the biliary tract not only contributes to hepatitis, but does so very frequently. Involvement of the biliary tract was detected in $45 \%$ of our patients. Its presence was mainly evident from:

1. Drainage data, showing -

(a) bile flow abnormalities (Bengolea and Velasco-Suarez, 1953; Labo and Lenzi, 1949; Lenzi, 1952) (Fig. 1);

(b) sediment alterations, which formed a thick layer of epithelial cells and leucocytes (Bengolea and VelascoSuarez, 1953; Labo and Lenzi, 1949; Lenzi, 1952) (Fig. 2);

(c) chemical and electrophoretic changes in bile which we have come upon on some other occasions (Sotgiu, Labo and Vannini, 1962).

As regards bile flow, patients with hepatitis can be roughly divided into two groups, though there is no firm dividing line between one category and another. In one group the quantity of bile found is remarkable, if one considers that we are dealing with cases of hepatitis; while in the second group, the duodenal juice remains for a long time very poor in bile. Schematically we can call the first group "full biliary tract type" or better: hepato-angiobiliary type and the second "empty biliary tract type" $\vec{\circ}$ or better, strictly hepatic type. As I shall $\overrightarrow{\vec{\omega}}$ have occasion to point out later, we havee reason to think that in the first group the्ठ parenchymal lesion is not severe and is accom-3. panied by considerable inflammation of the lower biliary tract. In the second type, on the $\vec{A}$ contrary, the parenchymal lesion and the intra-जे hepatic cholestasis, "facteur complementairev dans la prolongation de la jaunisse" (Albot,, 1962) dominates the whole picture.

In addition to duodenal drainage data thereare a number of other reasons for implicating damage to the biliary tract in hepatitis, namely:

2. Possibly successful therapy by duodenate drainage. In some cases of the first group reer noticed that after one or more drainages the stool suddenly became darker, while ictertsos regressed rapidly as if after the release of ${ }^{-} a$ mechanical obstruction (Bengolea and Velasco-o Suarez, 1953; Brulé, Cottet and Hamburger.o 1934; Brulé, Cottet and Netter, 1935; Caroli 1954; Harvier and Antonelli, 1934).

We have seen many such cases.

3. Characteristics of the clinical picture From a clinical point of view these patients sometimes appear, so to say, more "icteric"s than "hepatic", more icteric than suffering. In the initial preicteric stage, or at the onset of icterus, the patient presents very markedg dyspeptic symptoms (due to acute gastro duodenal involvement) which later disappearo though the icterus worsens and becomes quite cholestatic. It is often then, of course, a mattero of intrahepatic cholestasis; but in other cases however, with biliary drainage it is possible to obtain a considerable quantity of bile and an rapid decrease in the jaundice, though the्్ functional and biopsy signs of hepatitis remain Sometimes peritoneoscopy may show a distended gall-bladder.

4. We know that the colour of the skin and bilirubinemia do not indicate exactly the re- 0 establishment of the bile-flow in the intestine. What is important is the rate of urobilinogen excretion in the stool. If we measure this 


\section{A.B.a.39-Q-ACUTE HEPATITIS \\ OIL CC $40 \downarrow$
NOVOCAIN CC $20 \$$ \\ INTRAVENOUS PROSTIGMINE $\downarrow$}
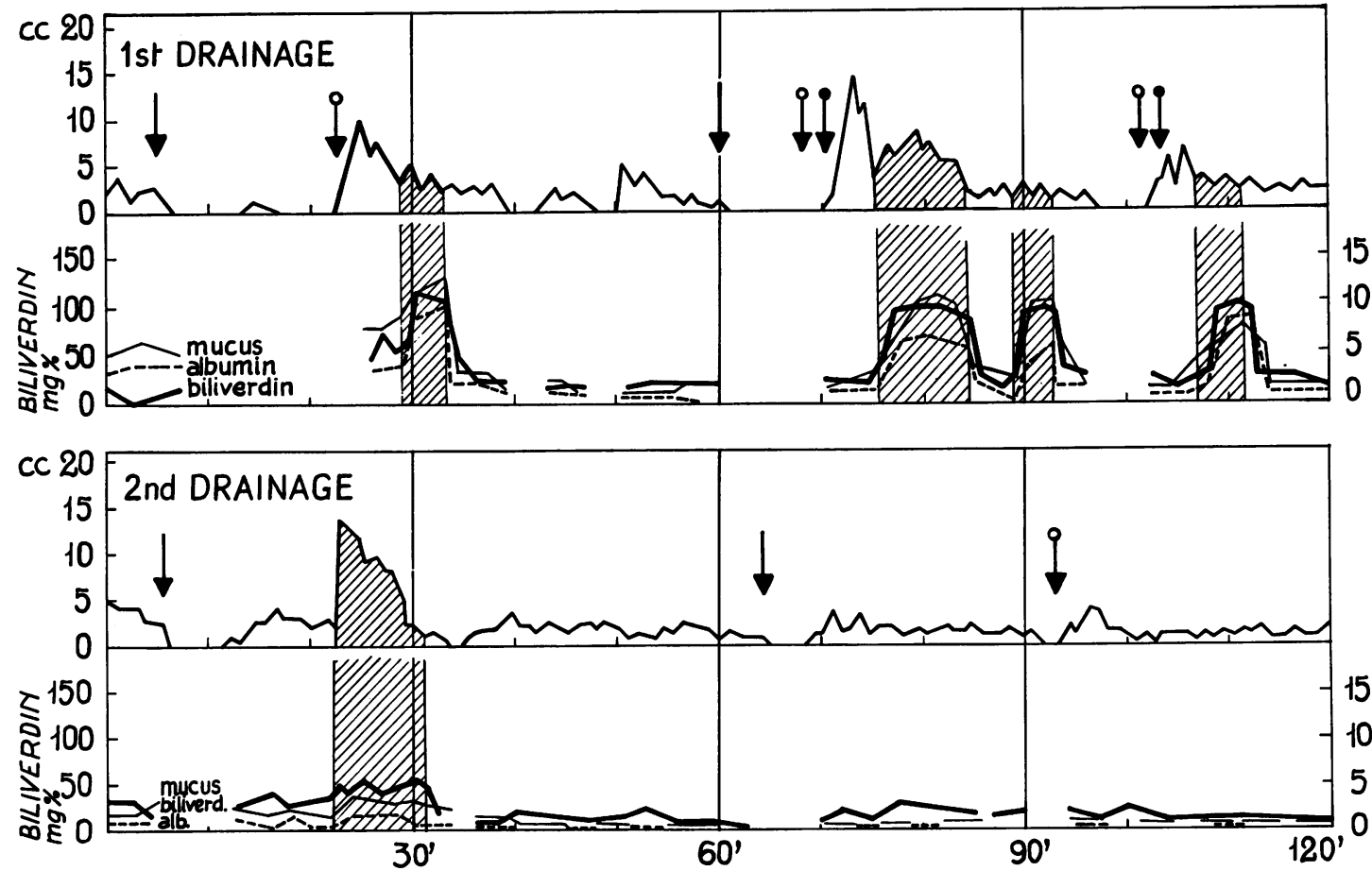

FIG. 1.-(a) "Hepatic type" of hepatitis. First drainage, at stage of developing jaundice. No bile is obtainable, notwithstanding repeated stimuli. Second drainage, during recovery stage. Fractions of bile fairly rich in biliary pigments can be obtained, although with some difficulty.

serially we find that in some cases the recovery of bile flow occurs quickly with a marked increase in stercobilin excretion. This may perhaps be ascribed to sudden improvement in parenchymal function, but it must be admitted that it is more easily explained by previous bile retention in the biliary tract. This is still more impressive if the behaviour of the pancreatic juice is also considered. This often shows a remarkable parallelism (Fig. 4) that demonstrates the existence of the "pancréatite satellite" of Loeper (Loeper, 1937; Loeper and Soulie, 1932) and sometimes suggests indeed the idea of some inflammatory obstacle at the level of the ampulla of Vater.

5. Biopsies have shown that the duodenal mucous membrane is very often quite obviously inflamed (Labo and Lenzi, 1949) (Fig. 5). In some cases also radiological examination indicates swelling of the ampulla of Vater (Fig. 2, 6).
6. In those cases in which the hepatitis assumes a prolonged course ("ictère catarrhal prolongé") and the jaundice has a cholestatic character, a decision may be taken after a time to operate either because there is doubt of the diagnosis of hepatitis and we suspect an occlusion or even because (though we are sure of the hepatitis) we see that the icterus is not responding to medical treatment. The literature, especially when hepatitis was called catarrhal jaundice, contained many descriptions of such cases, to which I have drawn attention on other occasions (Sotgiu, 1956).

What does the surgeon find in these cases? Let us omit those in which there is pancreatitis (Mallet and Jean-Jeary, 1946; MacDonald and Drysdale, 1943), an actual papillitis (Baggenstoss, 1938; Eppinger, 1938; Sarles, 1950) or enlarged lymph glands (Brulé and David, 1934; Loeper, 1937; Loeper and Soulie, 1932). In other cases the common bile duct and/or 
G.C. a.25- Q - ACUTE HEPATITIS
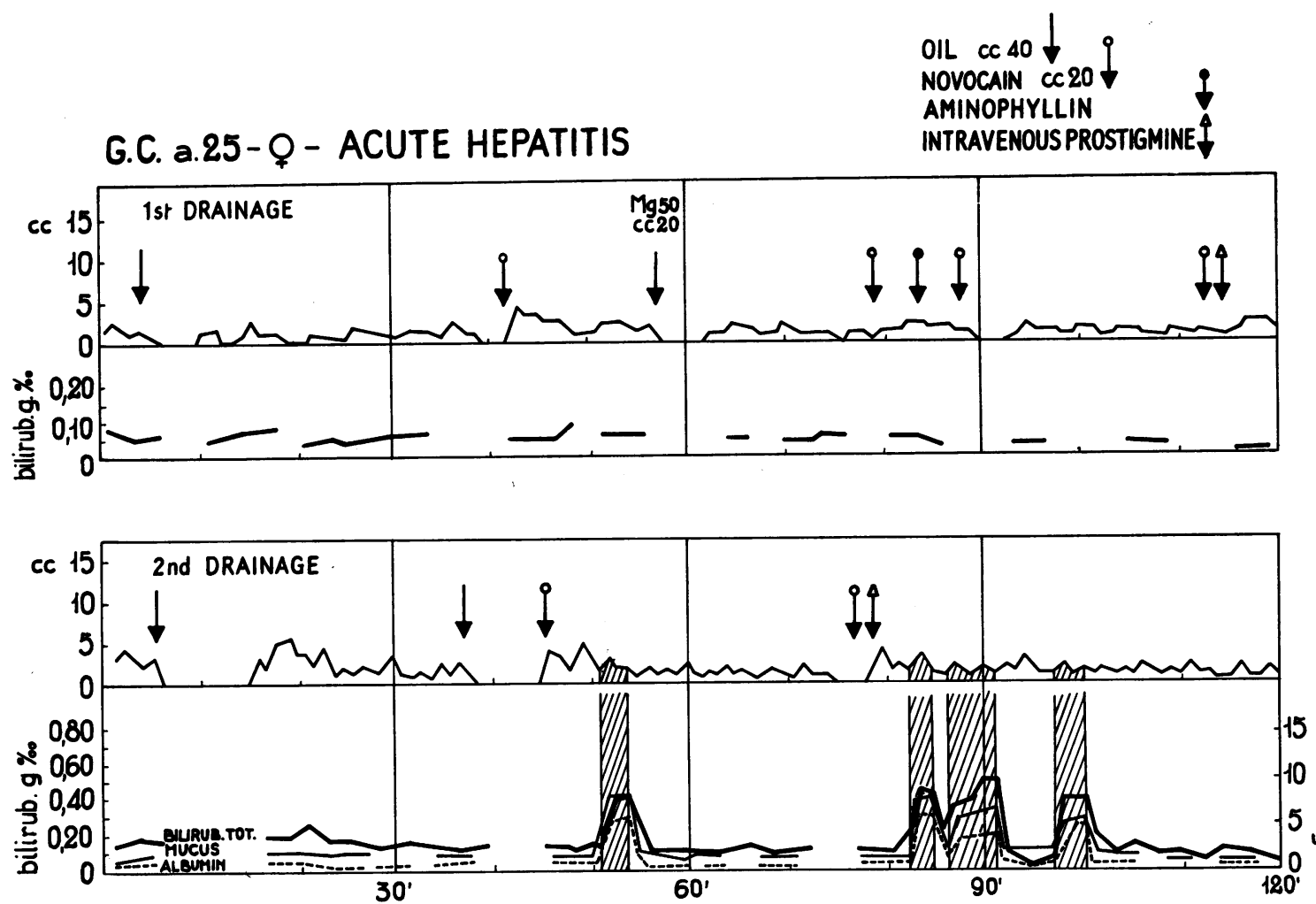

Fig. 1.-(b) "Hepato-angiobiliary type" of hepatitis. First drainage at stage of developing jaundice. By repeated stimuli, fractions of bile $B$ and $C$ are obtained. "Time of closed Oddi" prolonged. Second drainage during recovery. The result is normal both with regard to the "time of closed Oddi" and the emptying of the gall bladder.

the ampulla, appear full of dense mucous and may be inflamed, oedematous and thickened (Backhaus, 1929; Benoit, 1935; Bergareche, 1941; Bergenfeld, 1944; Charrier and Thalheimer, 1929; Fragenheim, 1929; Haberer, 1932; Hurst and Simpson, 1934; MacDonald and Drysdale, 1943; Matsuo and Mizuta, 1925; Mirizzi, 1948; Nordmann, 1925; Oliver, 1951; Pribram, 1948; Rovsing, 1924; Soupault, 1949), while in others they seem completely normal. If the surgeon, being uncertain about the origin of jaundice, performs in these cases a cholecystgastrostomy, we observe that almost always the jaundice regresses rapidly, even if the bile duct seems perfectly normal (Caroli, 1954). We have 9 such cases. If the jaundice does not diminish, it is evident that it was due to an intrahepatic cholestasis. In the other cases we are forced to admit that the operation has provoked a restoration of bile flow.

In such cases there are several observations to be made. Firstly, it is true that cholangiography and cholangiomanometry do not show the existence of any obstruction to bile-duct emptying in hepatitis, but I do not think this objection is a sound one. The parenchyma being affected, bile pressure sinks to a very low level, to even a very few-two or three-centimetres of water. Under such conditions the least obstruction, such as that resulting from mucous membrane swelling and exudation would be sufficient to obstruct bile flow. The mucous evidently accumulates in consequence of the stopping of the biliary flow. This all gives rise, therefore, to a sort of vicious circle, in which jaundice is maintained, even though parenchymal changes are improved. Flushing is sufficient to re-establish the biliary flow (Macdonald and Drysdale, 1943). Cholangiography and cholangiomanometry will not show such small lesions.

Secondly, one might suggest that an operation affects through stress as a biological stimulus 

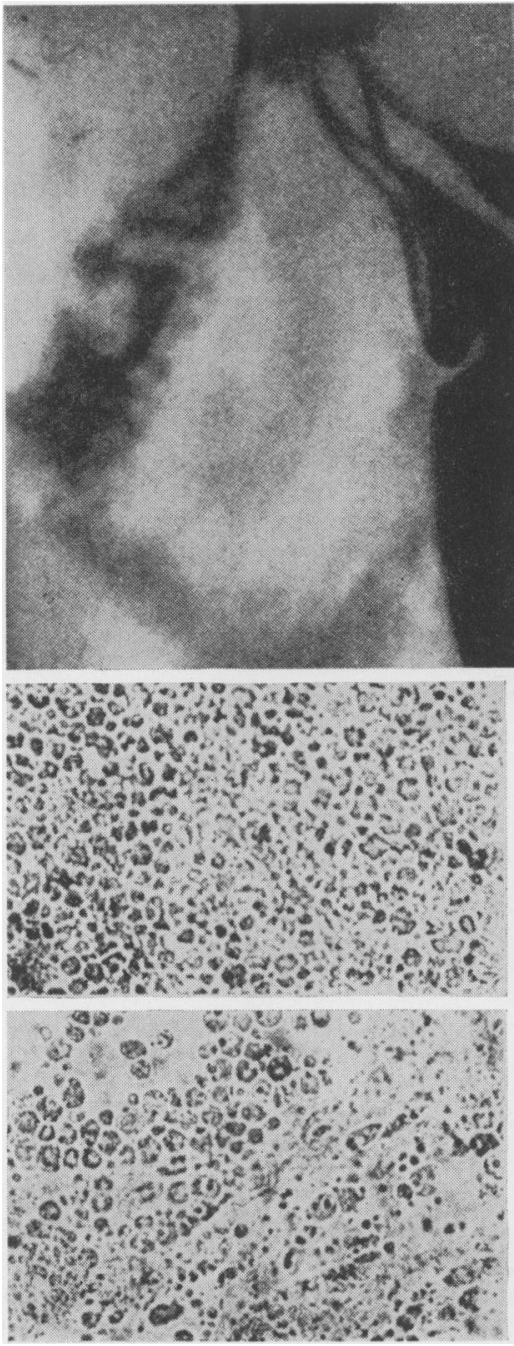

by a nervous or hormonal mechanism, the evolution of hepatitis and intrahepatic cholestasis. Though admissible, this is hypothetical. From my point of view, I prefer to explain the results of a surgical operation with a clear, physical explanation, rather than by any functional, complex and purely hypothetical one.

7. As we know, many of the frequent sequelae of hepatitis arise in the biliary ducts. These consequence are: cholecystitis, dyskinesia, stenosing cholangitis, papillitis, etc. How can one ever explain these after-effects if you do not admit that the biliary ducts too undergo inflammation during hepatitis?

These points are illustrated in Figures 1-8. A short schematic table summarises the two types, "hepato-angiobiliary" and the purely "hepatic" (Table 1).

It is not strange that a century after Virchow we do not yet recognise the morphologic basis of such a common disease as benign hepatitis. This happens (1) just because it is a benign disease, for which therefore little autopsy material exists, (2) because from a time when we used to explain the whole matter with the lesion of the biliary tract, we have passed to another period in which we would explain the whole matter with the parenchymal lesion. We can overcome the difficulties if we admit that with the hepatitis (which always exists) there may also often be an involvement of the large bile ducts and those adjacent. In this way we can reconcile such discordant reports and of duodenum showing a filling defect that may be ampulla of Vater.

Below : sediments of crainage bile formed by a epithelial cells. 


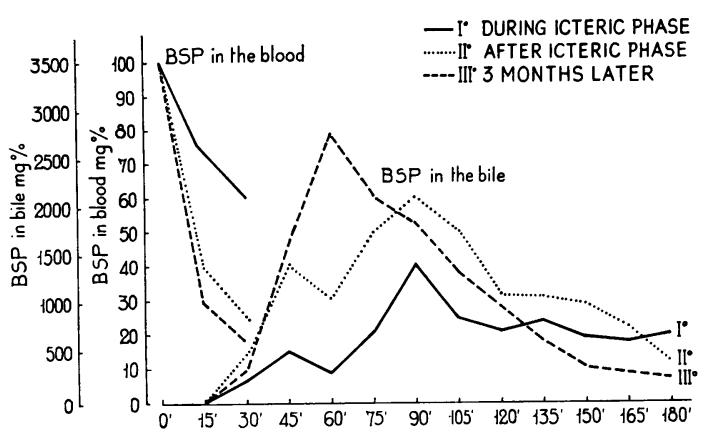

FIG. 3.-(a) B.S.P. studies-"Hepatic" type-the "B.S.P. appearance time" in bile is normal during the acute stage.

(b) "Hepato-angiobiliary" type--"B.S.P. appearance time" is augmented as in cases with known obstruction to bile flow. It diminishes after antispasmodics and at stage of recovery.

\section{B.A. a.57-O- ACUTE HEPATITIS}

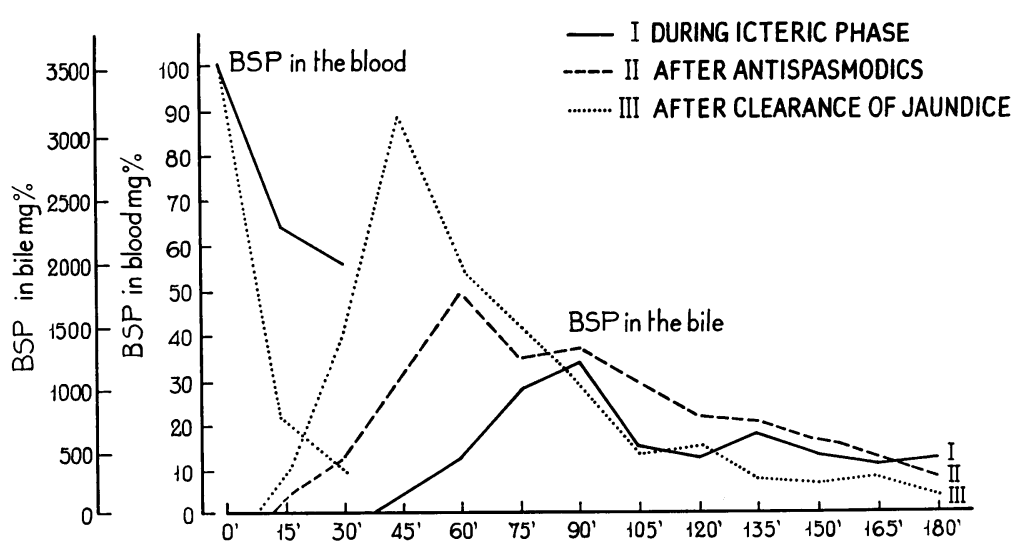

opinions (besides the above mentioned authors, see also Holmgren, 1938; Pavel, 1944 (spasm theory), Pribram, 1948; Royer, 1964; Ryska, 1902; Toelg and Neusser, 1884, and see the criticism of Caroli, 1950). If we invoke involvement of the biliary tract, as a "complementary factor", this does not mean we go back to Virchow's "mucous plug" theory. Virchow thought this was primary, as he did not know anything about hepatitis as we conceive it today, while we think the accumulation of exudate, when present is secondary.

\section{Summary and Conclusions}

1. The large bile ducts are frequently involved in hepatitis;

2. Involvement in certain cases contributes to the persistence of the jaundice;

3 . The presence of these lesions raises certain important questions with regard to the treatment of such patients. Specific medical treatment (chiefly duodenal drainage for therapeutic purposes) and sometimes even surgery may be indicated to relieve the biliary obstruction. If an attack of jaundice which started as hepatitis and in which cholestasis develops does not respond to treatment and cannot be ascribed to intrahepatic cholestasis, we must consider not merely a neoplastic or extrinsic obstruction (such as lymphatic glands or pancreatitis), but also a simple involvement of the biliary tract, together with-possibly subsequent to - the parenchymal lesion.

This all shows once more how complicated

FIG. 4.-Pancreatic enzymes in hepatitis.

(a) The retention and release of biliary pigments occur at the same time as the retention and release of pancreatic ferments.

(b) levels of amylase in blood, urine and stools in cases of hepatitis related to the serum bilirubin level. Increased retention of amylase is observed when bilirubin blood level is increased, while it returns to normal when jaundice disappears.

Key:

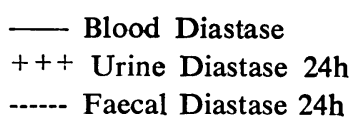
$\frac{0}{\circ}$ $\frac{\bar{D}}{\bar{D}}$ 


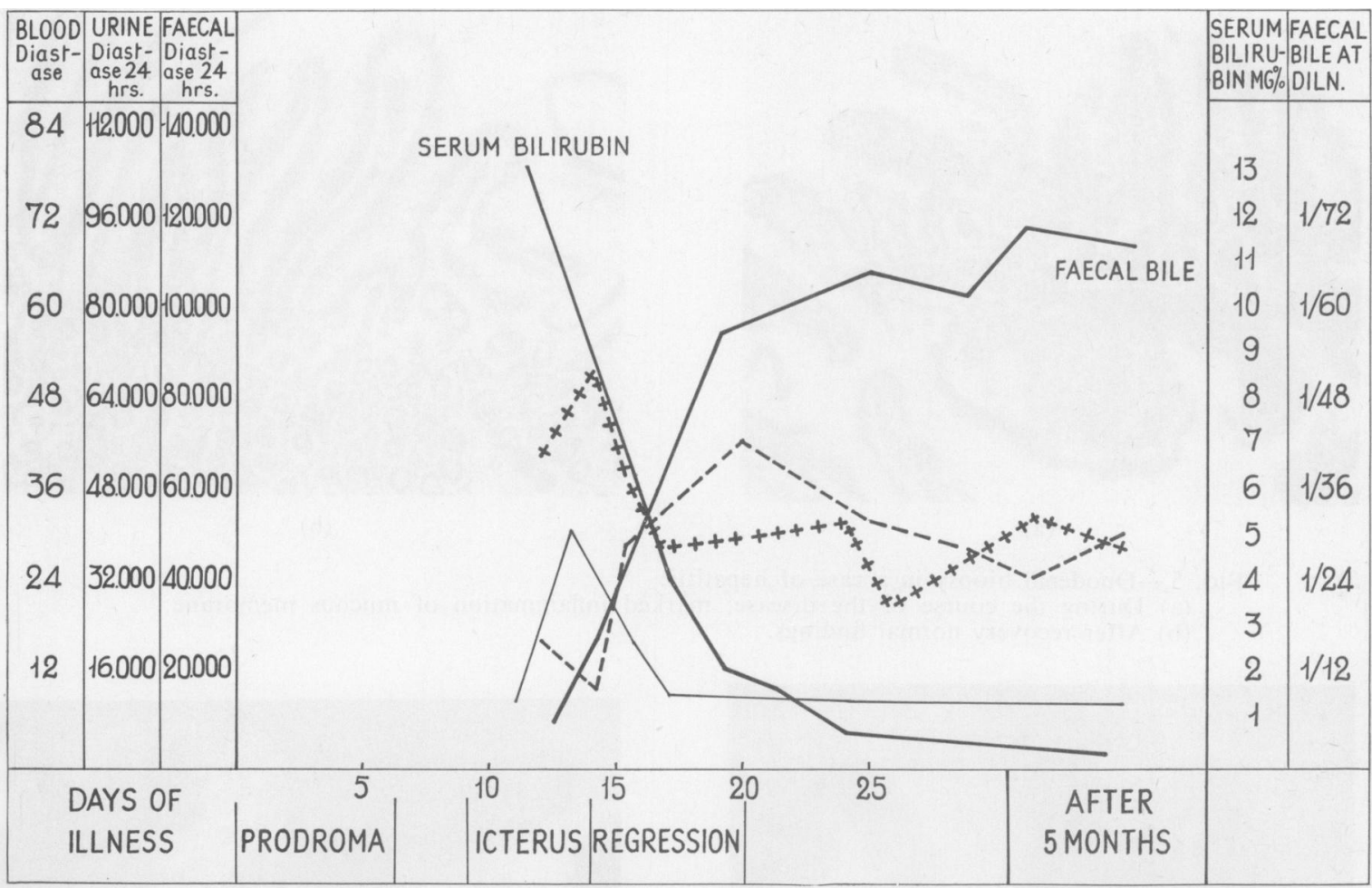

(a)

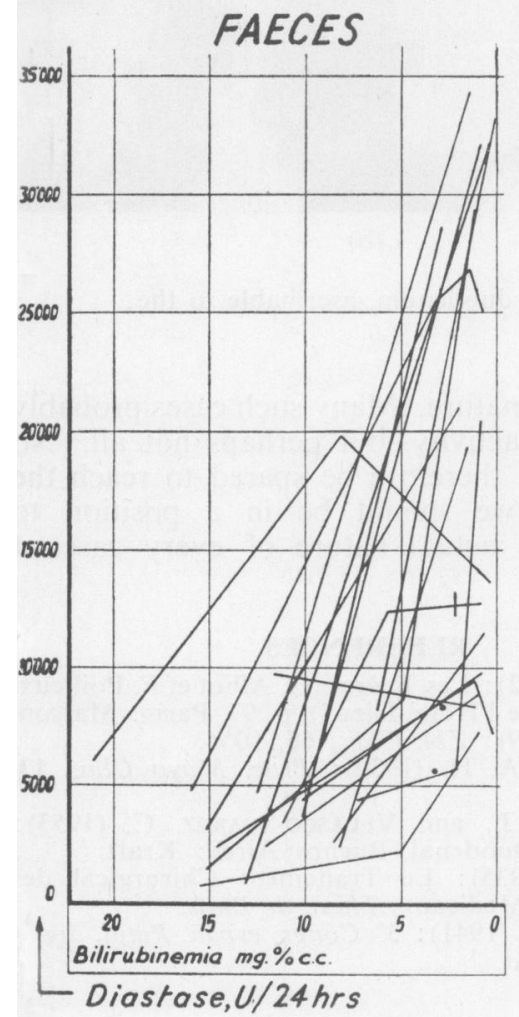

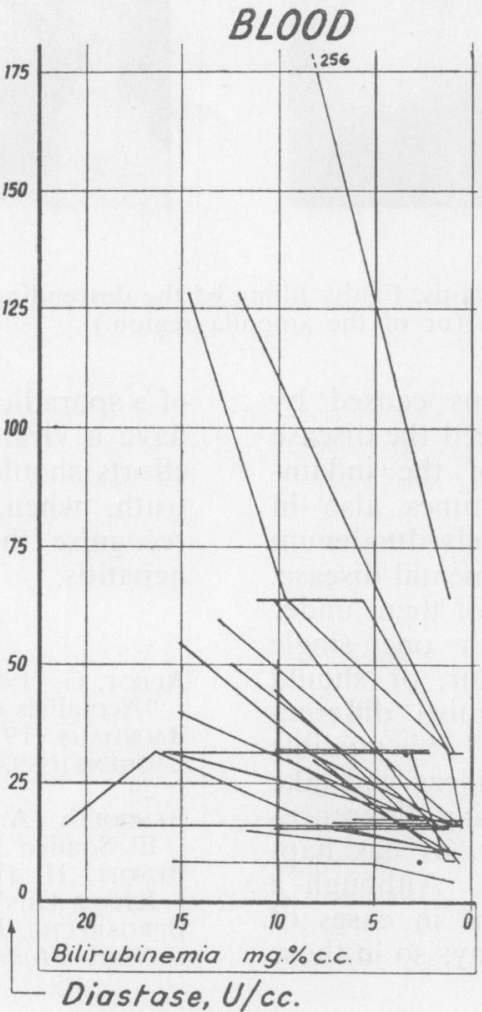

(b)

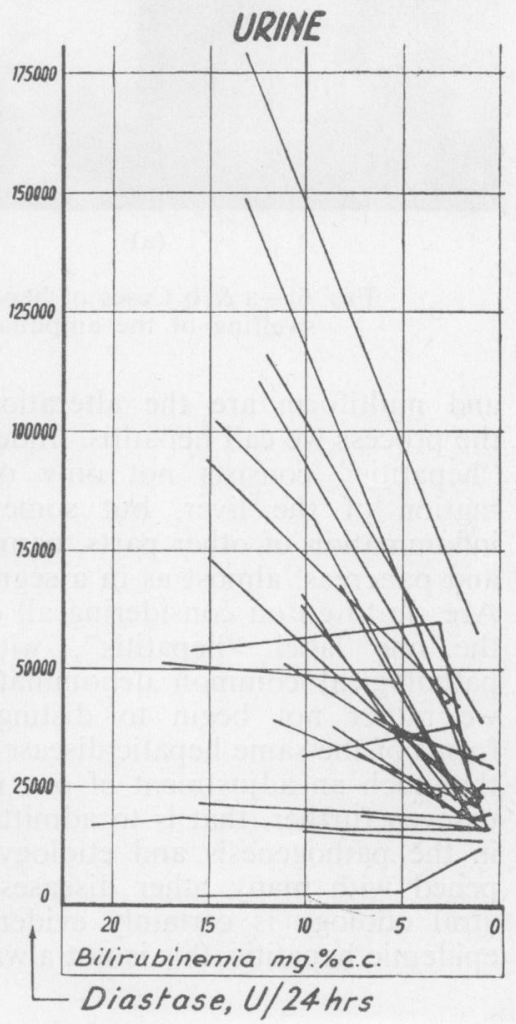

URINE

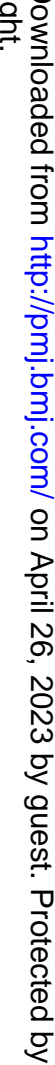

FIG. 4 


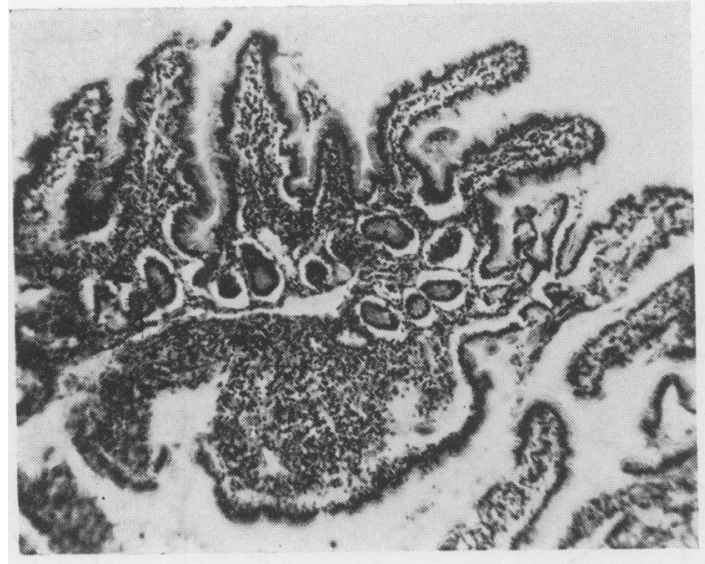

(a)

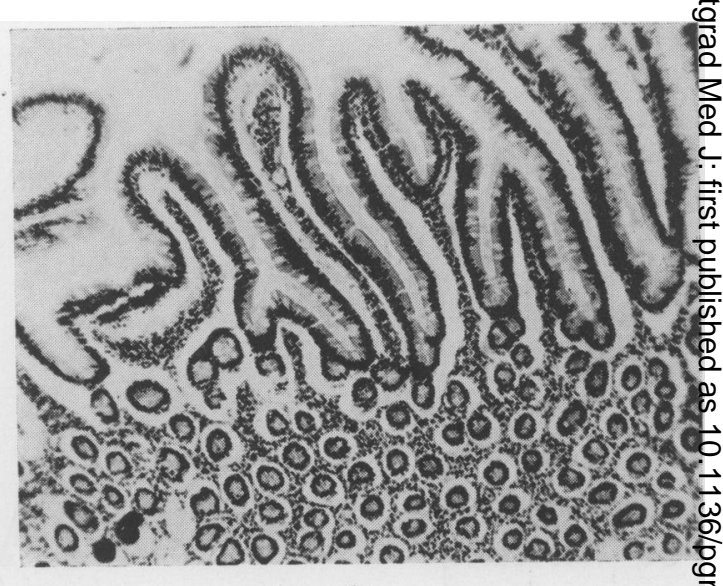

(b)

FIG. 5.-Duodenal biopsy in a case of hepatitis:

(a) During the course of the disease; marked inflammation of mucous membrane;

(b) After recovery normal findings.

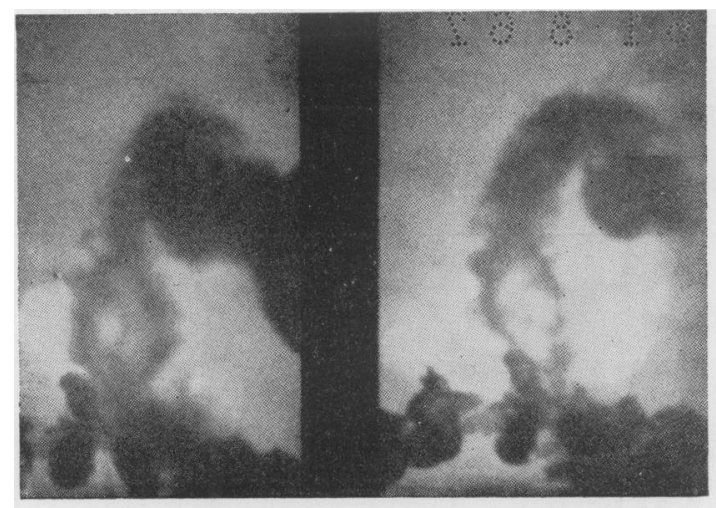

(a)

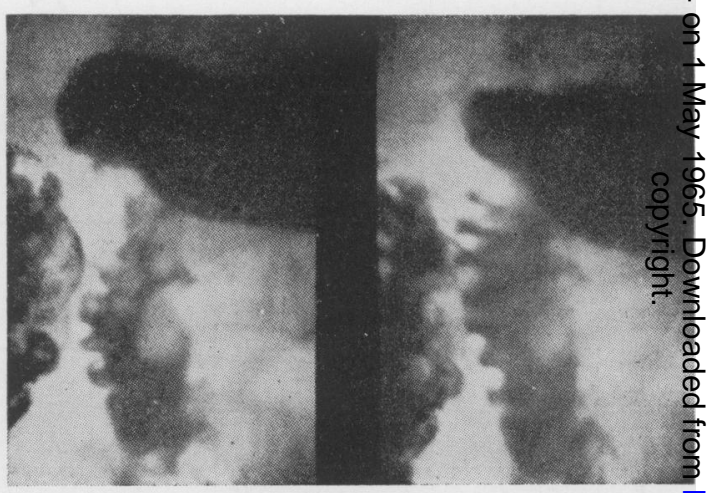

(b)

FIG. 6.- $a$ \& $b$ Cases of hepatitis. Faulty filling of the descending duodenum, ascribable to the swelling of the ampulla (or of the ampulla region.)

and multiform are the alterations caused by the process we call hepatitis. Indeed the disease "hepatitis" consists not only of the inflammation of the liver, but sometimes also in inflammation of other parts, namely duodenum and pancreas, almost as in a segmental disease. Are we to go on considering all of them under the one label "hepatitis", with one single pathological common denominator, or should we rather not begin to distinguish different forms of the same hepatic disease? It is possible that such an adjustment of our ideas will take us even further, that is to admitting differences in the pathogenesis and etiology, as has happened with many other diseases. Although a viral etiology is certainly evident in cases of epidemic hepatitis, this is not always so in those of a sporadic nature. Many such cases probabe have a viral activity, but perhaps not all. $N$ Q efforts should therefore be spared to reach the truth, when we should be in a position to recognise the actual nature of every case of hepatitis.

\section{REFERENCES}

Albot, G. (1962): Les Ictères (G. Albot et F. Poilleu "Actualités de l'Hôtel-Dieu"), p. 97, Paris: Masson Backhaus (1929): Zbl. Chir., 56, 1054.

Baggenstoss, A. H. (1930): Proc. Mayo Clin., 俵 29.

Bengolea, A. J., and Velasco-Suarez, C. (1953) El Sondeo Duodenal, Buenos Aires: Kraft.

BENOIT, H. (1935): Le Traitement Chirurgical ded Ictères Dits Medicaux, Thèse de Paris.

Bergareche, J. (1941): $3^{\circ}$ Congr. españ. Patol. dig. Nutr., Madrid. 


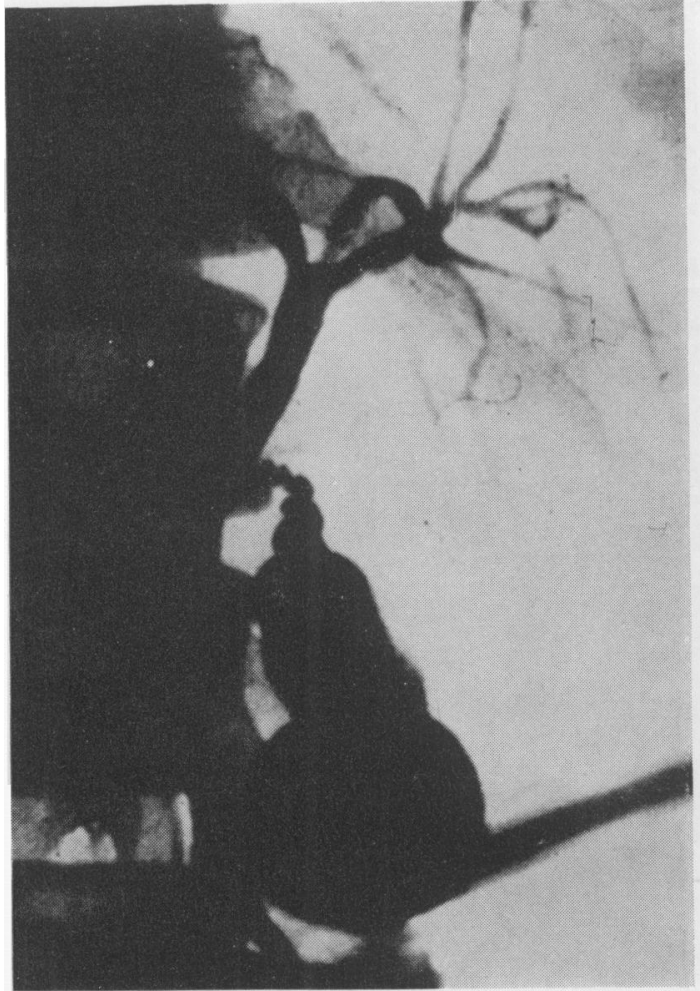

(a)

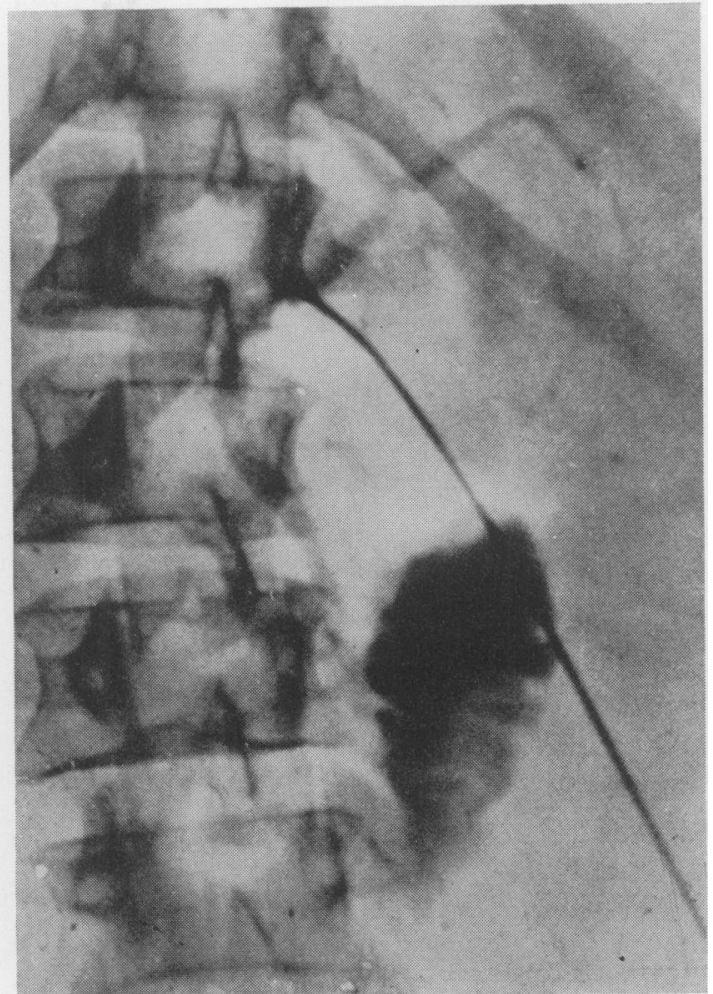

(b)

FIG. 7.-Cases of prolonged hepatitis treated sugically. Operative cholangiography.

(a) Well visualized biliary ducts.

(b) Poorly visualized, thread-like high biliary ducts. The common bile duct has a normal outline but is very pale.

TABLE 1

\begin{tabular}{|c|c|c|}
\hline & \multicolumn{2}{|c|}{ Hepatitis } \\
\hline & Pure hepatic form & Hepato-angiobiliary form \\
\hline $\begin{array}{l}\text { Clinical criteria: } \\
\text { preicteric symptoms } \\
\text { onset of jaundice } \\
\text { patient's appearance } \\
\text { result : recovery } \\
\text { no recovery }\end{array}$ & $\begin{array}{l}\text { mainly general } \\
\text { gradual } \\
\text { icteric and suffering } \\
\text { slow } \\
\text { acute atrophy }\end{array}$ & $\begin{array}{l}\text { mainly gastric (dyspeptic) } \\
\text { rapid } \\
\text { icteric rather than suffering } \\
\text { rapid } \\
\text { chronic jaundice, obstructive type }\end{array}$ \\
\hline $\begin{array}{l}\text { Laboratory criteria: } \\
\text { biological tests } \\
\text { duodenal drainage } \\
\text { bile flow } \\
\text { signs of bile retention } \\
\text { X-ray } \\
\text { peritoneoscopy }\end{array}$ & $\begin{array}{l}\text { markedly positive } \\
\text { not difficult } \\
\text { very poor } \\
\text { few and slight } \\
\text { biliary ducts not evident } \\
\text { gall-bladder flaccid }\end{array}$ & $\begin{array}{l}\text { faintly positive } \\
\text { difficult } \\
\text { often not poor or abundant } \\
\text { many and marked } \\
\text { biliary ducts sometimes evident } \\
\text { gall-bladder not flaccid }\end{array}$ \\
\hline $\begin{array}{l}\text { Therapeutic criteria: } \\
\text { effect of drainage }\end{array}$ & none & favourable \\
\hline
\end{tabular}




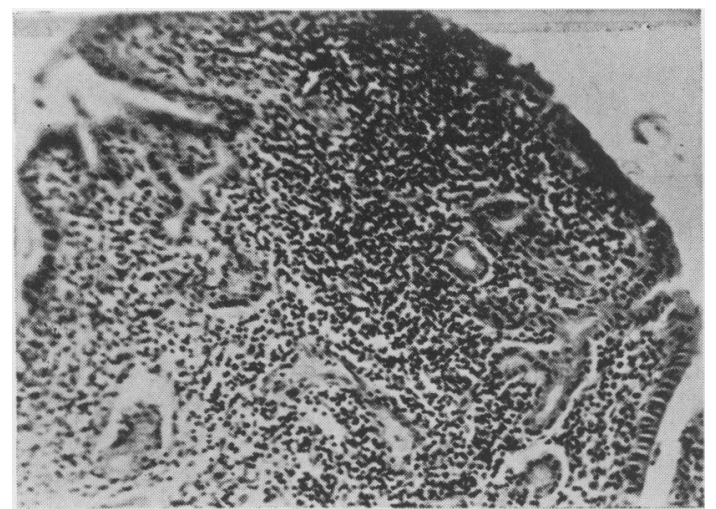

FIG. 8.-Cases of prolonged hepatitis treated surgically. Operative gall bladder biopsy. In both cases there is a remarkable inflammatory infiltration of the gall bladder wall.

Bergenfeld, E. (1944): Acta med. scand., 90, 329. BERGENFELD, E. (1948): ibid, 96, 17.

BERGENFELD, E. (1949): ibid, 98, 319.

Brule, M., Cottet, J., and Hamburger, J. (1934): Presse méd., 42, 1713.

Brul.e, M., Cottet, J., and NetTer, A. (1935): Bull. Soc. Méd. Paris, 51, 370.

Brule, M., and David, J. (1934): Presse méd., 42, 1049.

Carol, J. (1950): Les Papillites Icterigènes Primitives, Paris : Vigot.

Caroli, J. (1954): Les Ictères Hépatolytiques Prolongés (p. 124): (Le foie et la veine porteActualités hépat. de l'Hôtel-Dieu), Paris: Masson.

Charrier, J., and Thalheimer, M. (1929): Arch. Mal. App. Dig. 19, 542.

EPPINGER, H. (1908): Wien. Klin. Wschr., 21, 480.

EPPINGER, H. (1938): "Die Leberkrankheiten", Berlin: Springer.

FRAGENHEIM (1929): Zbl. Chir., 56, 1504.

HABERER, H. v. (1932): Med. Klin., 28, 425.

HABERER, H. v. (1933): Dtsch. Z. Chir., 239, 417.

HARvier, P., and ANTONelli, J. (1934): Paris méd., $1,420$.

Holmaren, J. (1933): Sved. För. f. inv. med. Förh. 1933 (p. 129) (quoted by Bergenfeld).

HuRST, A. F., and SIMPSON, C. K. (1934): Guy's Hosp. Rep., 84, 173.

Labo, G., Cavassini, G. B., Franco, T., and Lenzi, G. (1959): Arch. ital. Mal. Appar. Dig., 26, 35.

LABO, G., and LenZI, G. (1949): ibid, 15, 277.

LENZI, G. (1952): Boll. Soc. T.U.E. Med. int. (Bologna). 2, 123.

LOEPER, M. (1937): "Les Hépatites", (p. 29), Paris : Masson.

LOEPER, M., and SOUlie, P. (1932): Bull. Soc. méd. Paris, 48, 308.

Mallet, Guy G., and Jean-Jean, R. (1946): Lyon Chir., 41, 389.

Macdonald, D., and Drysdale, R. (1943): Amer. J. Surg., 60, 122.

Matsuo, I., and Mizuta, N. (1925): Acta Sch. med. Univ. Kioto, 8, 87.

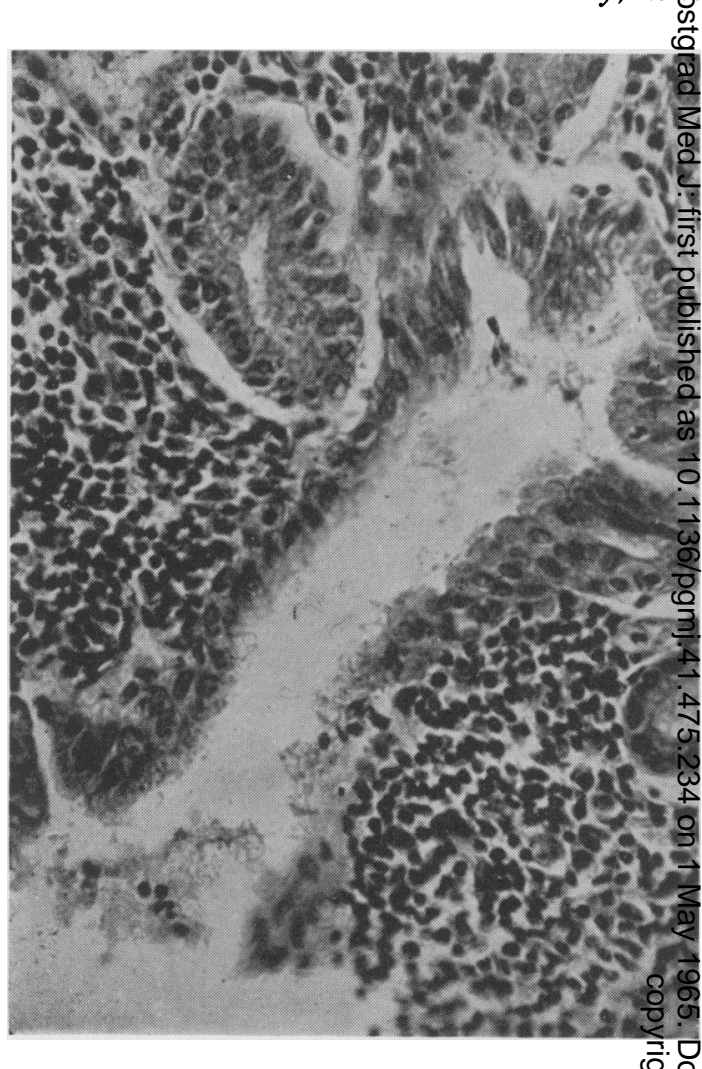

Mirizzi, P. (1948): Pren. méd. argent., 35, 313. NoRdManN, O. (1925): Med. Klin., 21, 1746 and 186. Oliver, E. (1951): Rev. esp. Enferm. Apar. dis. 10,154

Pavel, I. (1932): Presse méd., 40, 1948.

PAVel, I. (1944): Les Ictères, Bucarest.

Piccaluga, A., Cavassini, G. B., and Barbara, $\overline{\bar{\Phi}}$ (1963): Arch. ital. Mal. A ppar. Dig., 30, 325.

Pribram, O. (1948): Amer. J. Dig. Dis., 15, 397.

ROYER, M. (1964): Patologia de Las Vies Biliares, Buenos Aires: Hachette.

Rovsing (1924): Acta chir. scand., 56, 207.

RYSKA (1902): Prag. med. Wschr., 27.

SARLES, H. (1950): Arch. ital. Mal. Appar. Diog, 39, 997.

Sotgiu, G. (1950): Atti e Mem. Accad. d. Scienge (Bologna), 7 (s. $\left.\mathrm{X}^{\circ}\right), 147$.

SotgIU, G. (1951):' "Le ostruzioni dell 'epatocoledoco" (Relazione $52^{\circ}$ Congr. ital. Med. Int) Pozzi, Roma, 1951.

SotGiU, G. (1956): Clin. ter., 2, 85, 1956.

Sotgiv, G., LABO, G., and VANNINI, P. (a) $I^{\circ}$ Sympos. internat. Chianciano, 1959; (b) III $^{\circ}$ Sympes internat. Chianciano 1962; (c) Rev. Internat d'hépat., 12, 575, 1962.

SOUPAULT, H. (1949): Arch. arg. Enf. Apar. Dił 24, 188 .

TOELG, J., and NeUSSER, E. (1884): Z. klin. Meg 7,321 .

VIRCHOW, R. (1865): Virchow's Arch. path. Ana 32, 117 